\title{
Evaluation of antioxidant properties of secondary metabolites in aqueous extracts of Ficus thonningii blume tested on wistar rats
}

\begin{abstract}
Background: Peptic ulcer is a major public health problem that affects about $10 \%$ of world's population. It is a disease resulting from an imbalance between gastro protective and aggressive factors of the gastric mucosa. The treatment of this disease is usually long, expensive and also the difficulty in accessibility of the modern medications to the local population in rural zones. Peptic ulcer represent nearly $31.65 \%$ of cases of consultation in the services of gastroenterology in Cameroon. This makes poor patients rely on traditional medicine for their health problems. The objective of this study was to evaluate the antioxidant properties of secondary metabolites in aqueous extracts of Ficus. thonningii Blume tested on Wistar rats.
\end{abstract}

Material and methods: MDA, Catalase, Glutathione, Pepsin, SOD, ASAT, ALAT, Creatinine, $\mathrm{XO}$, total proteins, were quantified using standard techniques. Phytochemical screening of plant aqueous extract for secondary metabolites was done.

Results: The extraction yield of the hydro-ethanolic extract (50:50) of the bark of $F$. thonningii Blume was 17\%.

Phytochemical screening:The hydro-ethanolic extract had the greatest number of secondary metabolites at the end of the phytochemical screening. However, decoction and infusion extraction produced high level of polyphenol than the other extraction methods. Saponins was produced mainly from ethanolic maceration. The extract also showed a non-significant increase of SOD, Catalase and glutathione in the preventive and curative activity. A dosedependent significant decrease $\mathrm{p}<.05$ in MDA $\mathrm{p}<0,05$ in the preventive evaluation.

Conclusion: This study showed that the hydro-ethanolic extract of the mixture of the dried bark of Ficus thonningii Blume had a promising antioxidant activity at $500 \mathrm{mg} / \mathrm{kg}$. The administration of this extract at concentration up to $2000 \mathrm{mg} / \mathrm{kg}$ could have a potential effect of vascular protection and hepatic protection.

Keywords: Ficus thonningii stem bark hydro-ethanolic extract, phytochemical screening, antioxidant, wistar rat
Volume 9 Issue I - 2020

\author{
Jessica Ketchemen pougoue,' Estella Tembe \\ fokunang,' Eustace Bongham beringyuy, ${ }^{3}$ \\ Joseph ngoupayo, ${ }^{2}$ Borgia Nono njinkio,' \\ James Ajeck MBAH, ${ }^{4}$ John Dobgima \\ fonmboh, ${ }^{5}$ Bethelemy ngameni, ${ }^{2}$ Charles \\ Ntungwen fokunang \\ 'Department of Pharmaco-toxicology and Pharmacokinetics, \\ Faculty of Medicine and Biomedical Sciences, University of \\ Yaoundé I, Cameroon \\ ${ }^{2}$ Department of Pharmacognosy and therapeutic Chemistry, \\ Faculty of Medicine and Biomedical Sciences, University of \\ Yaoundé I, Cameroon \\ ${ }^{3}$ Department of Biochemistry, Faculty of Medicine and \\ Biomedical Sciences, University of Yaoundé I, Cameroon \\ ${ }^{4}$ Department of Chemistry, Faculty of Science, University of \\ Buena, Cameroon \\ ${ }^{5}$ Department of Bio Resources, college of technology, the \\ University of Bamenda, Cameroon
}

Correspondence: Charles Ntungwen fokunang, Department of Pharmaco-toxicology and pharmacokinetics, Faculty of Medicine and Biomedical Sciences, University of Yaoundé I, Cameroon, Tel +2376772077/2 Email fokunngestella@yahoo.co.uk

Received: January 20, 2020 | Published: February 27, 2020

\section{Introduction}

Treatment of this disease requires in most cases a combination of several molecules with specific mechanisms of action. This treatment has 4 goals: relieve pain, accelerate healing, prevent complications and reduce the frequency of relapses. But while effective, treatment using conventional medicines is not usually well attended by patients. ${ }^{1}$ The reasons included their high cost and low availability to a large majority of the population especially those living in rural areas. In many developing countries, the health infrastructure is poor and a large majority of the population, mainly rural, has no access to primary health care and modern medicines. These patients use the resources of traditional herbal medicine as an alternative treatment

However, traditional herbal medicine is facing a number problems for its vulgarisation including lack of sufficient studies on therapeutic properties as well toxicity tests to provide sufficient guarantees for their rational use. The common wild plant, $F$. thonningii, is extensively used in African ethno medicine for treating a number of disease conditions which include diarrhoea, urinary tract infections, diabetes mellitus, gonorrhoea, respiratory infections, and mental illnesses. The leaves of $F$. thonningii contain various bioactive compounds which include alkaloids, terpenoids, flavonoids, tannins and active proteins, all of which contribute to its curative properties. In vitro and in vivo pharmacological studies revealed that F.thonningii possesses antimicrobial, anti diarrheal, anti helmintic, antioxidant, anti-inflammatory and analgesic properties. Scientific research has validated the ethno medicinal claims that $F$. thonningii is useful in disease management. However, there is need to continue identifying, isolating and quantifying the active principles and possibly determine the mechanisms underlying the curative properties of its bark. ${ }^{2}$ It is in this context that the current study was conducted to investigate phyto chemically screen, evaluate the antioxidant of the stem bark extract on Wistar rats

\section{Materials and methods}

This was an experimental in vitro and in vivo preclinical study on Wistar rats conducted from the 11 November 2016 to the 25th May 2017. The study was done in the Preclinical Animal toxicology and 
Pharmacology Laboratory of the Faculty of Medicine and Biological Sciences, of the University of Yaoundé 1, Cameroon, while the quantification of biochemical parameters was done in the biochemistry laboratory of the same university.

\section{Ethical consideration}

Ethical approval was given by the institutional review board (IRB) of the Faculty of Medicine and Biomedical Sciences of the University of Yaoundé 1 and administrative authorization was obtained to conduct study in the animal house of this faculty.

\section{Collection, identification preparation of plant material}

Fresh stem barks were harvested after identification by a botanist from the plant growing at Bafoussam on the $03^{\text {rd }}$ of January 2017. The identified plant was authenticated at the National Herbarium of Cameroon by comparison with a sample having the voucher reference number 444042/HNC. The barks were dried under shade at room temperature for a period of three weeks in order to avoid solar radiations from altering the API. These barks were spread on plastic bags while avoiding their stacking. Every day we turned these barks upside down so as to favour a homogenous drying process. The dried barks were ground in a clean electric grinding machine in such a way to obtain a fined powder which was stored in an airtight container.

\section{Plant extract preparation}

Three types of extraction procedures were used in order to evaluate the in vivo activity and selected the extract with the best activity since there were no studies with respect the evaluation of the antiulcer activity of the bark of Ficus thonningii Blume. These methods of extraction were:

\section{Extraction by maceration}

In this process, the coarsely powdered crude plant was placed in a stoppard container with the solvent (distilled water, ethanol and hydro-ethanolic solution 50:50) and allowed to stand at room temperature for a period of 48 hours with frequent agitation until the soluble matter has dissolved. The mixture was then strained, the marc (the damp solid material) was pressed, and the combined liquids were clarified by filtration using Whatman paper. ${ }^{3}$

Infusion: By infusion, fresh infusion was prepared by mixing the crude plant or part of it for a short period of time specifically 10 to 15 minutes with initially boiling water. ${ }^{3}$

Decoction: By decoction, the crude plant was boiled in a specified volume of water for a defined time generally 10 to 15 minutes; it was then cooled and filtered. This procedure is suitable for extracting water-soluble, heat-stable constituents. The starting ratio of crude plant to water was fixed, 1:4 or 1:16; the volume was then brought down to one-fourth its original volume by boiling during the extraction procedure and the concentrated extract was filtered.

Yield determination of the extract:The best activity was shown with the hydro-ethanolic maceration.

Hence, after 48hours the macerate was filtered with Whatman No. 3 filtered paper and the collected filtrate was evaporated in an oven at $50{ }^{\circ} \mathrm{C}$. This extract was weighed in order to determine the yield obtained from the initial powder quantity and then stored in an airtight container for subsequent experimental tests.
The yield (\%) was gotten from the formula below:

$$
\text { Percentage yield }=\frac{\text { mass of the extract obtained }}{\text { mass of the initial plant powder }} * 100
$$

Animal testing: The animals used were white albino rats of the Wistar strain (Rattus norvegicus) aged between two and three months. These animals had an average weight of $178.2 \pm 22.09 \mathrm{~g}$ for the antiulcer activity and $125.5 \pm 10.14 \mathrm{~g}$ and $119.8 \pm 6.50 \mathrm{~g}$ respectively for the males and the females used in the assessment of acute toxicity. They were raised in the animal house of the FMBS Yaounde 1 under favourable conditions for their growth and development. The diet consisted of a mixture of corn meal(45\%), wheat flour(20\%), fish meal $(20 \%)$, soybean meal( $10 \%)$, palm kernel $(5 \%)$, bone flour for calcium intake $(0.98 \%)$, cooking salt $(0.5 \%)$ and vitamin complex $(0.5 \%)$. Two to three times a month, a vitamin complex (Olivitasol, Cedex, France) was added in their water to drink. Animal identification was done by cage card and corresponding bold marker body markings and they were maintained in the animal house of FMBS.

For animal selection, the animals were subjected to a gross observation to ensure that the selected rats were in a good health. Rats were randomly selected with respect to body weight for final allotment to the study. The animal environment was made up of natural air conditioned rooms with optimal air changes per hour, relative humidity, temperature and illumination cycles set to $12 \mathrm{~h}$ light and 12 hours dark. The animals were accommodated in groups housed in cages with stainless steel grill top, together with facilities for food and water bottle and bedding of clean paddy husk.

For administration of the test substance, the plant extract was administered by oral gavage to each rat with $1 \mathrm{ml}$ of the ulcerogenic substance, using an intubation needle fitted onto a syringe of appropriate size. The dose administered to individual rat was calculated according to its body weight recorded on the day of test substance administration. The anti-ulcer reference drug used was omeprazole (OMIZEC) 20mg batch number 260044 bought in a community pharmacy in Yaounde specifically on the 02 January 2017.

Phytochemical screening:The protocol of Odebiyi and Sofowora, et al., ${ }^{4}$ was used to carry out the different chemical tests. This screening process did not only allow us to test and evaluate the various solutions prepared but also to have an idea about the secondary metabolites present in these solutions. At the end of this process we observed that the hydro-ethanolic maceration has the greatest number of secondary metabolites.

Preparation of the hydro-ethanolic plant extract: The powder obtained after the grinding period were weighed and then $10 \mathrm{~g}$ of the powder were mixed with several fractions of a 50:50 hydro-ethanolic solution in order to obtain a final solution of $1000 \mathrm{ml}$ in a flat bottomed flask. This mixture was mixed several times within $48 \mathrm{~h}$ of maceration after which the mixture was filtered using Whatman paper number 3 . The macerate was dried in an oven at $50^{\circ} \mathrm{C}$ for three days. The dried extract obtained is then weighed in order to determine the yield from the initial powder used.

\section{Metabolite identification test}

\section{Alkaloid identification}

This was done using the Mayer Waltz test, Hager Test and the Wagner test respectively. ${ }^{5}$ 


\section{Polyphenol identification}

Tests was done using the Iron per chloride test, lead acetate test. ${ }^{4}$ In a test tube was introduced $2 \mathrm{ml}$ of the $1 \%$ extract and added a few drops of acetate of lead to $10 \%$. The formation of a white precipitate indicated the presence of polyphenols.

\section{Flavonoid identification tests}

Use of Sodium hydroxide test: Sulfuric acid test. ${ }^{6}$ In a test tube $2 \mathrm{ml}$ of the $1 \%$ extract was put and added a few drops of Sulfuric acid then allowing them to flow over the tube wall. The formation of an orange coloration indicated the presence of flavonoids.

\section{Identification test of anthocyanins}

To $5 \mathrm{ml}$ of $5 \%$ extract was added $5 \mathrm{ml}$ of $10 \% \mathrm{H}_{2} \mathrm{SO}_{4}$ followed by $5 \mathrm{ml}$ of ammonium hydroxide $\left(\mathrm{NH}_{4} \mathrm{OH}\right)$ diluted to half. In the presence of anthocyanin, the coloring was accentuated by acidification which turned into blue-purplish in basic medium. ${ }^{7}$

Test for identification of tannin $\left(\mathrm{FeCl}_{3}\right.$ Test): In a test tube was introduced $5 \mathrm{ml}$ of the $5 \%$ infused in which was added $1 \mathrm{ml}$ of dilute aqueous solution of $1 \%$ ferric perchloride $\left(\mathrm{FeCl}_{3}\right)$. The presence of tannins was indicated by blackish-blue or greenish coloration. ${ }^{8}$

Differentiation of catechic and gallic tannins: It was obtained by the reaction of stiasny, which was carried out in the following manner. To $30 \mathrm{ml}$ of infused solution was added $15 \mathrm{ml}$ of STIASNY reagent $(10 \mathrm{ml}$ of $40 \%$ formalin more $5 \mathrm{ml}$ of concentrated $\mathrm{HCl}$ ) and heated for 15 minutes in a water bath at $90^{\circ} \mathrm{C}$. With catechic tannins a precipitate showed their presence and for gallic tannins after filtration the filtrate was saturated with powdered sodium acetate, then $1 \mathrm{ml}$ of a solution of $1 \%$ ferric perchloride $\left(\mathrm{FeCl}_{3}\right)$. The presence of gallic tannins was not precipitated by the Stiasny reagent was indicated by the development of dark blue shade.

Mucilage Identification Test: To $1 \mathrm{ml}$ of decoctate at $10 \%$ was added $5 \mathrm{ml}$ of absolute ethanol. The obtaining of a fluffy precipitate indicated the presence of mucilages. ${ }^{10}$

\section{Test for the identification of saponins}

The Foam Test: $100 \mathrm{ml}$ of the decoction at $1 \%$ were distributed in 10 test tubes numbered from 1 to 10 Successively $1,2,10 \mathrm{ml}$. The volume of each tube was adjusted to $10 \mathrm{ml}$ with distilled water. Each tube was stirred for 15 seconds in the length direction and then left to settled for 15 minutes and was observed for a persistence of the foam. ${ }^{1}$

Steroid Identification Test: $\mathrm{In} 1 \mathrm{ml}$ of extract was added $2 \mathrm{ml}$ of acetic anhydride then $2 \mathrm{ml}$ of sulfuric acid obtaining a violet colour. This colour turned blue or green to indicate the presence of steroids. ${ }^{11}$

Test for identification of resins: In a test tube was added $2 \mathrm{ml}$ of the $1 \%$ extract then a few drops of anhydrous acetic acid solution followed by $1 \mathrm{ml}$ of sulfuric acid $\left(\mathrm{H}_{2} \mathrm{SO}_{4}\right)$ The appearance of a yellow colour indicated the presence of resins. ${ }^{12}$

Test for identification of cardiac glycosides (Keller-Killani test $^{13}$ : In $0.5 \mathrm{ml}$ of the extract was added $2 \mathrm{ml}$ of glacial acetic acid and a few drops of $5 \%$ Ferric Chloride $\left(\mathrm{FeCl}_{3}\right)$ solution, then $1 \mathrm{ml}$ of concentrated sulfuric acid. The Formation of a greenish or brown ring at the interface indicated the presence of glycosides.

Test for identification of quinones: In a test tube, put $2 \mathrm{ml}$ of $1 \%$ extract. Add $2 \mathrm{ml}$ of concentrated $\mathrm{H}_{2} \mathrm{SO}_{4}$. Obtaining a red colour indicated the presence of the quinones. ${ }^{14}$

\section{Identification test for betacans}

In a test tube was put $2 \mathrm{ml}$ of the $1 \%$ extract then added $2 \mathrm{ml}$ of $2 \mathrm{~N}$ $\mathrm{NaOH}$ and the tube was heated in a boiling water bath for 5 minutes. The appearance of a yellow coloration indicated the presence of betacyane. ${ }^{15}$

\section{Identification test for coumarins}

In a test tube containing $1 \mathrm{ml}$ of the plant extract $1 \mathrm{ml}$ of distilled water was added with a few drops of $10 \% \mathrm{FeCl}_{3}$. Obtaining a green or blue coloration that later turned yellow by addition of nitric acid $\left(\mathrm{HNO}_{3}\right)$ indicated the presence of coumarins. ${ }^{16}$

\section{Oxalate identification test}

In a test tube, was put $2 \mathrm{ml}$ of the $1 \%$ extract then added a few drops of ethanolic acid to obtain a greenish-black colour which indicated the presence of oxalates. ${ }^{17}$

\section{Quantification of biochemical parameters in gastric juice and homogenates pepsin ${ }^{6,18}$}

Pepsin was used as a bio marker for the integrity of the gastric mucosa. In an acid medium, it hydrolyzed the peptide bonds of the proteins which contained the aromatic amino acids to give the polypeptides which, in the presence of the Folin reagent, gave a violet blue complex which exhibited a maximum absorption at $660 \mathrm{~nm}$. The intensity of the staining was proportional to the amount of polypeptide present in the solution.

\section{Catalase $^{19}$}

The catalase assay was performed according to the method described by Sinha. $0.9 \mathrm{ml}$ of phosphate buffer $(0.01 \mathrm{M}, \mathrm{pH} 7)$ and $0.4 \mathrm{ml}$ of $\mathrm{H}_{2} \mathrm{O}_{2}$ were introduced into each tube to initiate the reaction. The reaction was interrupted after 30 seconds by the introduction of $2 \mathrm{ml}$ of dichronic acetic acid. The whole was heated at $100^{\circ} \mathrm{C}$ for 10 minutes. After cooling, the optical density was read at $570 \mathrm{~nm}$. The amount of hydrogen peroxide remaining in the solution after addition of the perchloric acid was evaluated using the calibration curve. The specific activity of catalase was expressed in $\mu \mathrm{M} \mathrm{H}_{2} \mathrm{O}_{2} / \mathrm{min} / \mathrm{mg}$ protein.

\section{Glutathione $^{20}$}

Reduced glutathione assay was performed according to the method described by Ellman (1959). The 2,2-dithio-5,5'-dibenzoic acid (DTNB) reacted with the SH groups of the glutathione to form a yellow coloured complex which absorbed at $412 \mathrm{~nm}$.

\section{Malondialdehyde (MDA) ${ }^{21}$}

The method used for the MDA assay was that of Wilbur et al., ${ }^{21}$ Carbonyl compounds such as malondialdehyde from the decomposition of fatty acid hydro peroxides react with thiobarbituric acid (TBA) to give pink chromophores whose concentration was determined by reading the absorbance at $532 \mathrm{~nm}$.

\section{Superoxide dismutase (SOD) ${ }^{22}$}

Principle according to Mishra and Fridovich., ${ }^{22}$ Adrenaline (epinephrine), in the presence of the superoxide anion $\mathrm{O}_{2}$, was oxidized spontaneously to adrenochrome; A colored compound which absorbed at $490 \mathrm{~nm}$. SODs, whose role was to reduce the $\mathrm{O}_{2}$ anion, inhibited this reaction 


\section{Expression of results:}

$$
\text { inhibition } \%=\frac{100-\Delta \text { A sample }}{\Delta \text { AWhite }} \times 100
$$

The specific activity of SOD was evaluated in units of SOD/ $\mathrm{mg}$ of protein. A unit of SOD was defined as the amount of SOD required to cause an inhibition of $50 \%$ of the oxidation of adrenaline to adrenochrome for one minute.

\section{Proteins $^{23}$}

The quantification of proteins was done following the procedure described by lowry. This was described in the table below. The tubes were incubated for a period of 30 minutes at room temperature under shade, then read the optical density at $600 \mathrm{~nm}$ against the blank.

\section{Xanthine oxidase ${ }^{25}$}

The quantification of xanthine oxidase was done following the procedure described by Rousso et al.., ${ }^{25}$

\section{Statistical analysis}

The results were expressed in terms of mean \pm standard deviation. The comparisons between the groups were analyzed using one-way analysis of variance, the ANOVA test followed by Turkey's Kramer post hoc test using the GraphPad Instat version 5.0 software. A P-value of less than 0.05 was considered statistically significant.

\section{Results}

\section{Extraction yield}

The extraction yield of the hydro-ethanolic extract (50:50) of the bark of $F$. thonningii Blume was $17 \%$ that was selected for use in the study.

\section{Phytochemical screening}

The hydro-ethanolic extract had the greatest number of secondary metabolites at the end of the phytochemical screening as shown in table 1. However, decoction and infusion extraction produced high level of polyphenol than the other extraction methods. Saponins were produced mainly from ethanolic maceration (table 2).

Table I Description of the protein quantification

\begin{tabular}{lll}
\hline Put in the test tubes & Sample & white \\
\hline Sodium hydroxide 0.IN & $190 \mu \mathrm{L}$ & $200 \mu \mathrm{L}$ \\
Gastric juice & $10 \mu \mathrm{L}$ & \\
Solution C & $1000 \mu \mathrm{L}$ & $1000 \mu \mathrm{L}$ \\
Incubate for 10 minutes & & \\
Solution D & $100 \mu \mathrm{L}$ & $100 \mu \mathrm{L}$ \\
The tubes were then vortexed & & \\
\hline
\end{tabular}

Table 2 Presentation of the secondary metabolites in the aqueous extract of the bark of $F$. thonningii Blume

\begin{tabular}{|c|c|c|c|c|c|c|}
\hline Test & Specific test & DEC & INF & ET MAC & H/E MAC & AQ MAC \\
\hline \multirow[t]{2}{*}{ Polyphenols } & $\mathrm{FeCl}_{3}$ & $\ldots+$. & $\ldots++$ & . & $*$ & . \\
\hline & lead acetate & $\ldots$ & .+ & . & . & - \\
\hline Saponin & & . & .. & $\ldots$ & .* & - \\
\hline Mucilage & & - & - & - & - & - \\
\hline \multirow[t]{3}{*}{ Alkaloids } & WAGNER & _- & _- & . & . & - \\
\hline & MAYER & - & - & . & . & - \\
\hline & HAGER & _- & _- & . & . & _- \\
\hline \multirow[t]{2}{*}{ Flavonoids } & $\mathrm{NaOH}$ & . & . & . & . & _- \\
\hline & $\mathrm{H}_{2} \mathrm{SO}_{4}$ & . & . & . & . & . \\
\hline \multirow[t]{3}{*}{ Tannins } & $\mathrm{CU}_{2} \mathrm{SO}_{4} / \mathrm{NH}_{3}$ & . & . & . & . & _- \\
\hline & catechic & . & . & . & . & _- \\
\hline & gallic & _- & - & - & - & - \\
\hline Steroids & acetic anhydride & - & - & - & - & - \\
\hline \multirow[t]{2}{*}{ Coumarines } & $\mathrm{FeCl}_{3}$ & . & . & - & _- & - \\
\hline & $\mathrm{HNO}_{3}$ & . & . & . & + & - \\
\hline Oxalate & & - & - & - & - & - \\
\hline Quinones & & . & . & _- & . & . \\
\hline beta cyanide & & - & - & - & - & - \\
\hline Phlobo tannins & & . & . & . & . & - \\
\hline Antho cyanide & & . & . & . & . & _- \\
\hline Cardiac glycosides & & - & - & - & - & - \\
\hline Resins & & . & . & _- & _ & _ \\
\hline
\end{tabular}

DEC- Decoction; INF- Infusion; ETMAC-Ethanolic maceration/E-Hydroethanolic maceration;AQ- Aqueous maceration;- represents the absence of metabolites, + represents the presence of metabolites, ++ abundant and +++ very abundant, ++++ extremely abundant 


\section{Quantification of biochemical parameters to evaluate the oxidative stress}

For catalyse quantification, there was a gradual increase of the catalyse concentration across the negative control group to the healthy animal group (Figure 1). MDA quantification showed a significant dose-dependent decrease in MDA in the groups receiving the extract as compared to the negative control group, though it was highest in the $500 \mathrm{mg} / \mathrm{Kg}$ group. The MDA content was lowest in healthy groups than omeprazole (Figure 2)

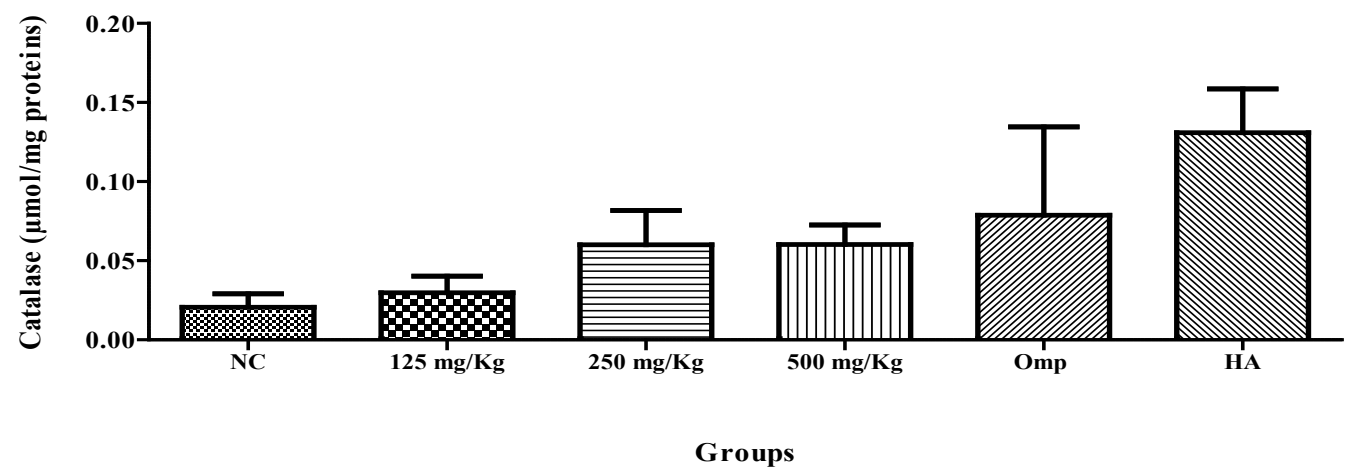

Figure I Effect of the hydro-ethanolic extract of $\mathrm{F}$. thonningii Blume on the concentration of catalase $(\mathrm{P}<0.05)$. p. NC=Negative control; Omp=Omeprazole, healthy animal.

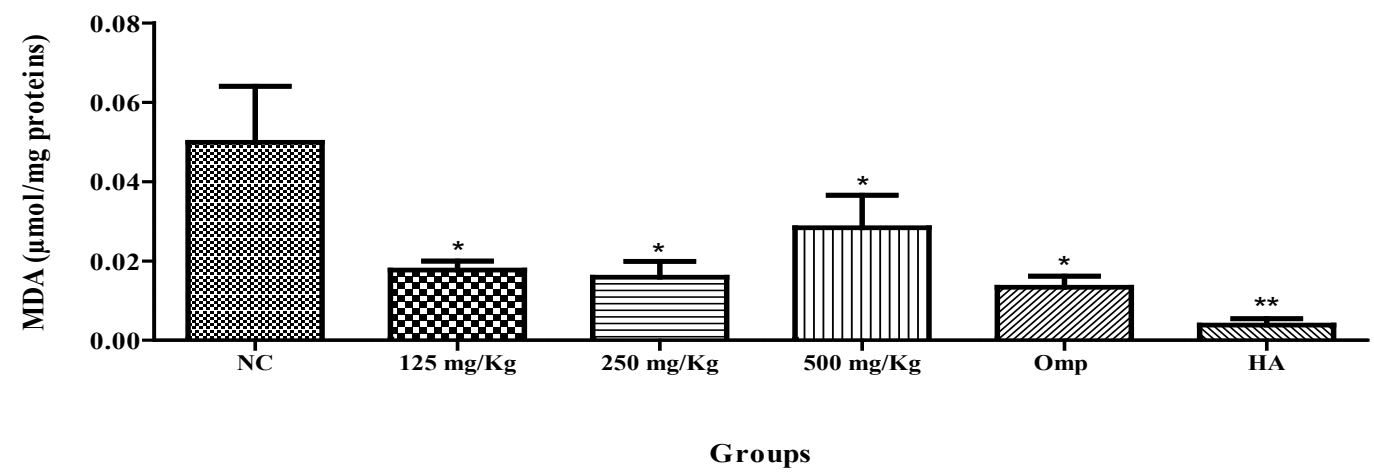

Figure 2 Effect of the hydro-ethanolic extract of $F$. thonningii Blume on the concentration of MDA $(P<0.05)$.

Glutathione: There was no significant variation in the glutathione level, but amongst the test groups, the $500 \mathrm{mg} / \mathrm{Kg}$ group has the highest level as compared to the negative control group (Figure 3).

Sulfoxide dismutase (SOD): There was no significant variation in the glutathione level, but the healthy animal (HA) group had the highest level as compared to the negative control group (figure 4). Variation of pepsin concentration, mucus concentration and gastric juice.
There were no significant changes at all the extract concentration for pepsin and mucus concentration compared to the positive control omeprazole. However, a significant difference $(\mathrm{p}<0.05)$ was observed across the dose range when compared to the positive control (Table 3 ). There was a great reduction of gastric juice $3,00 \pm 1,66$ at $500 \mathrm{mg} / \mathrm{Kg}$

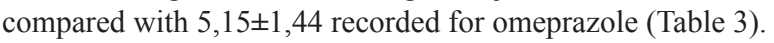

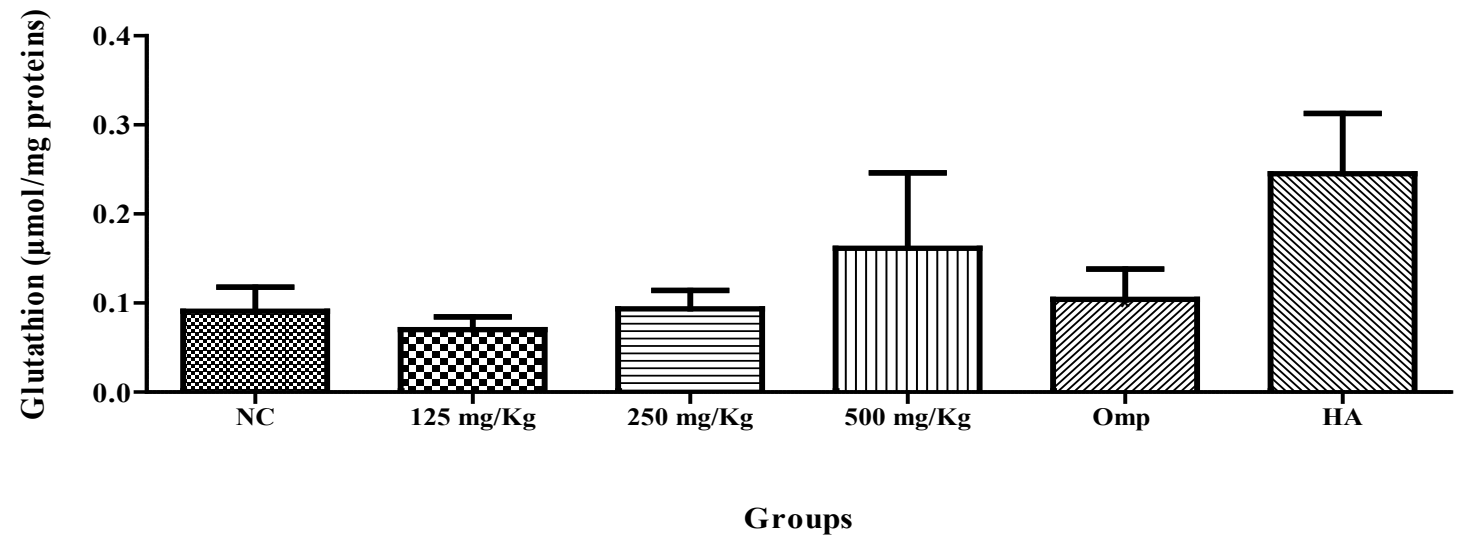

Figure 3 Effect of the hydro-ethanolic extract of F. thonningii Blume on the concentration of glutathione $(P<0.05)$. 


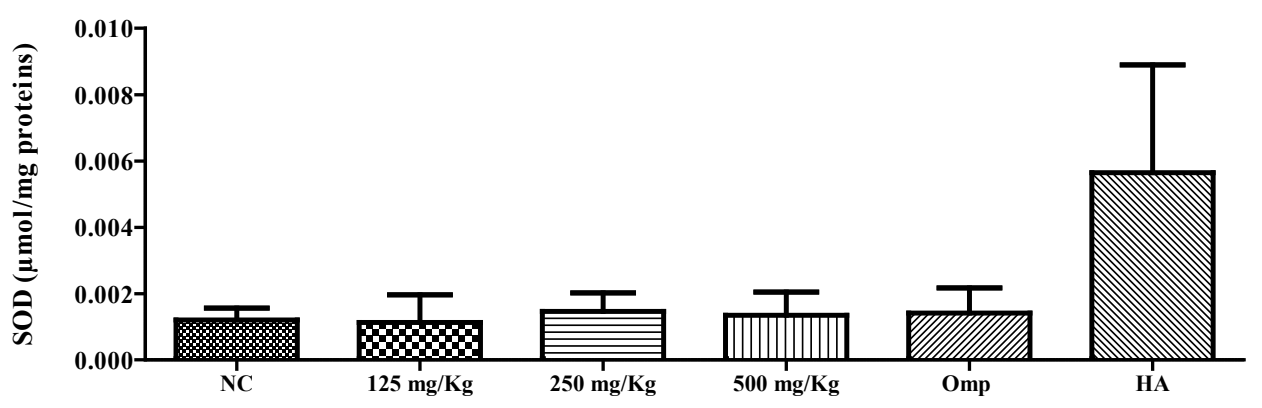

Groups

Figure 4 Effect of the hydro-ethanolic extract of F. thonningii Blume on the concentration of SOD $(P<0.05)$.

Table 3 Effect of the hydro-ethanolic extract of F. thonningii Blume on the concentrations of pepsin and mucus, as well as the gastric juice variation $(P<0.05)$

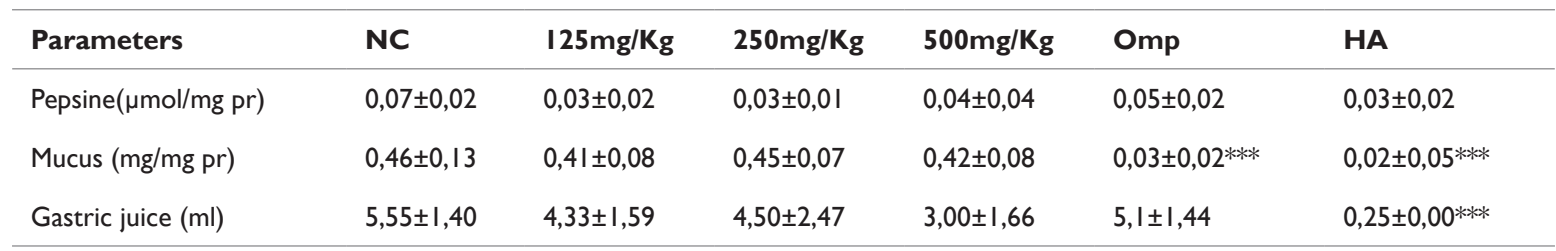

Pr- proteins, NC-negative control, HA- healthy animals, Omp- omeprazole

\section{Quantification of the biochemical parameters to evaluate the oxidative stress}

Glutathione: There was no significant variation in the glutathione level, but amongst the test groups, the $500 \mathrm{mg} / \mathrm{Kg}$ group has the highest level as compared to the negative control group (Figure 5).
Catalyse: There was a dose dependent increase in catalyse activity with increasing dose from $125 \mathrm{mg} / \mathrm{kg}$ body weight to $500 \mathrm{mg} / \mathrm{kg}$ body weight (Figure 6) At high dose of extract $500 \mathrm{mg} / \mathrm{kg}$ there was increased catalyse activity compared to the reference drug omeprazole. There is a gradual increase of the catalyse concentration as we move from the negative control group to the $500 \mathrm{mg} / \mathrm{Kg}$ group (Figure 6)

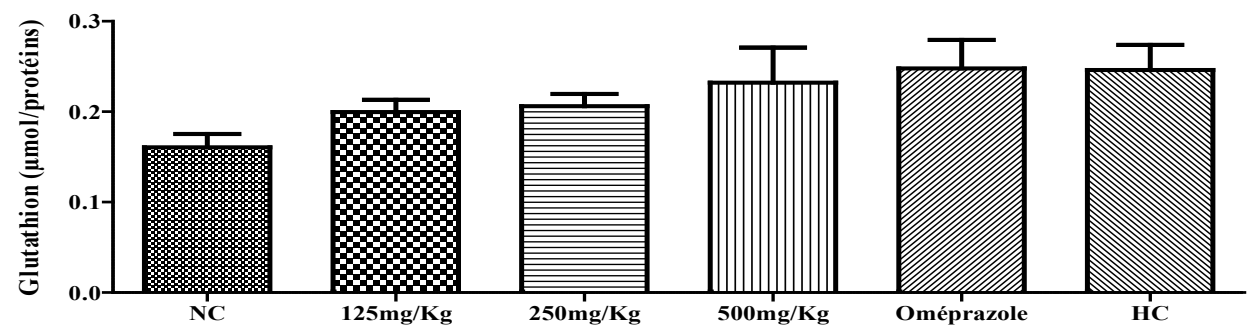

Groups

Figure 5 Effect of the hydro-ethanolic extract of $F$. thonningii Blume on the concentration of glutathione $(P<0.05)$.

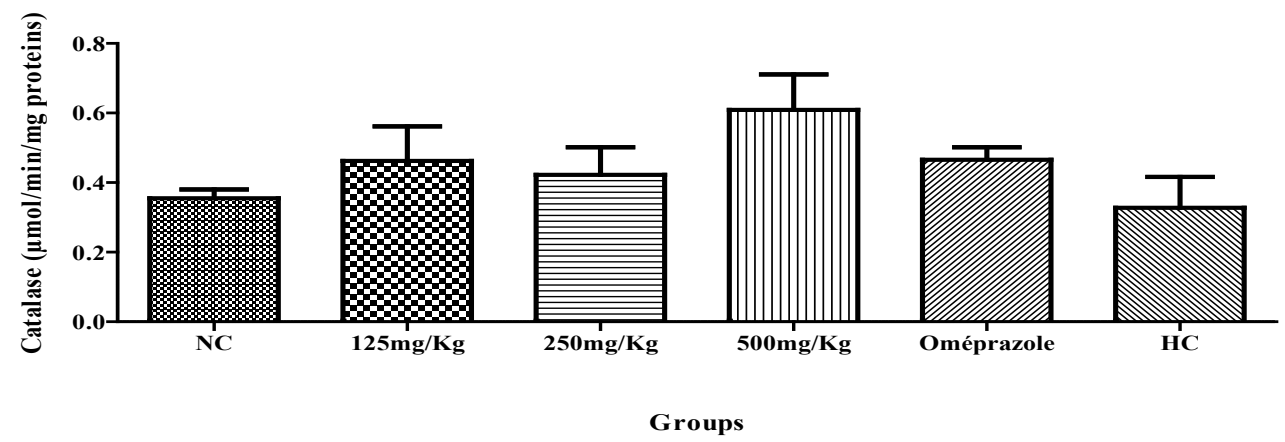

Figure 6 Effect of the hydro-ethanolic extract of F. thonningii Blume on the concentration of catalase $(\mathrm{P}<0.05)$. 
Malondialdehyde (MDA): There was a significant difference in the decrease in MDA activity compared to the negative control (Figure 7). However, the decrease in MDA among the extract dose ranges were not significant compared with the reference drug omeprazole, but significant difference could be seen when compare to healthy animal treatments (Figure 7). There was very little MDA. We observed a nonsignificant dose-dependent decrease in MDA in the groups receiving

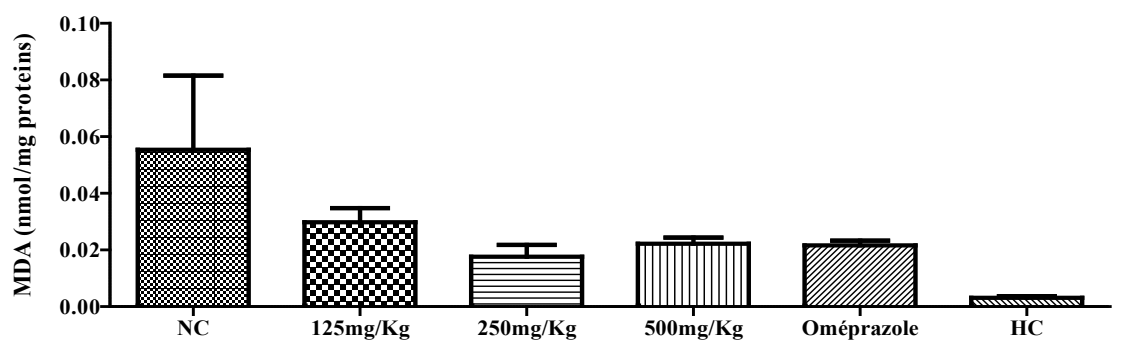

Groups

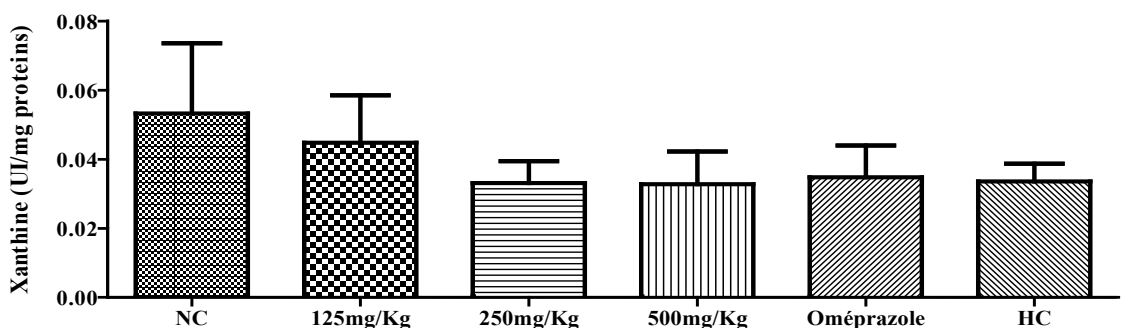

Groups

Figure 8 Effect of the hydro-ethanolic extract of F. thonningii Blume on the concentration of Xanthine Oxidase $(P<0.05)$.

\section{Discussion}

Belonging to the family of Moraceae, the genus Ficus is among the largest genera of angiosperms, from about 60 are present in Cameroun. ${ }^{3,12,26}$ In our search of bioactive compounds from Cameroonian medicinal plants of the Ficus, we examined the hydroethanolic extract of the bark of $F$. thonningii Blume on peptic ulcers induced by absolute ethanol. Ethanol exposes the mucosa to the proteolytic and hydrolytic actions of hydrochloric acid and pepsin, ${ }^{7,28}$ causing damage to the membrane, ${ }^{13}$ stimulates acid secretion, increases activity of xanthine oxidase, triggers imbalances in cellular antioxidant processes, reduces mucosa microcirculation and increases apoptosis. ${ }^{16,29}$

In this study, the results of the phytochemical screening showed that the hydro-ethanolic stem bark of $F$. thonningii Blume contained various biologically active compounds called phytochemicals, which are naturally produced by the plant as protection against biotic and abiotic stresses. The main groups of phytochemicals isolated from the prepared extract solution included; polyphenols, saponins, alkaloids, flavonoids, catechic tannins, coumarins, quinones, phlobotanins, anthocyanins which corroborates with the work done by Dangarembizi. in 2013 on the leaves of $F$. Thonningii, ${ }^{10,30}$ and Usman et al. ${ }^{5}$ in $2010 .{ }^{31}$ These metabolites are similar to those found in F. Sycomorus $;^{7,32}$ Phytochemicals such as alkaloids have anti-depressive and antiinflammatory effects in which some have preventive and curative the extract as compared to the NC, though it was high in the $500 \mathrm{mg} /$ $\mathrm{Kg}$ group. The MDA content was lowest in healthy groups (Figure 7).

Xanthine oxidase: There was a non-significant dose-dependent decrease in Xanthine oxidase in the groups receiving the extract as compared to the control treatments. However, the decrease was significant from $250 \mathrm{mg} / \mathrm{kg}-500 \mathrm{mg} / \mathrm{kg}$ that was comparable to omeprazole (Figure 8). 
F. thonningii Blume stem bark hydro-ethanolic extract at all doses $(125,250$ and $500 \mathrm{mg} / \mathrm{Kg})$ have reduced the ulcer total surface area when compared to the negative control group $(\mathrm{P}<0.05)$ where the greatest percentage of inhibition was observed by the $500 \mathrm{mg} /$ $\mathrm{Kg}$ group of rats $(92.94 \%)$ but not significantly. This results did not corroborate with the Curative treatment of detoxified pericarp extract of Anamirta cocculus fruit given orally at a dose of $(200 \mathrm{mg} / \mathrm{kg})$ and roxatidine (positive control) administered at a dose of $(100 \mathrm{mg}$ / $\mathrm{kg}$ ) which induced a significant curative effect. The anti-ulcer drug, roxatidine and detoxified pericarp extract of Anamirta cocculus fruit significantly inhibited ulcer formation by $81.06 \%$ and $54.49 \%$ respectively when compared with control $(\mathrm{p}<0.001){ }^{32,40-41}$ The present finding suggests that $F$. thonningii Blume stem bark hydro-ethanolic extract promote ulcer protection as ascertained by the comparative decrease in ulcer surface area and percentage inhibition of ulcers. In the present alcohol-induced gastric ulcer model, the levels of glutathione, catalase and MDA increased in the $500 \mathrm{mg} / \mathrm{Kg}$ group as compared to the negative control. These compounds are important for maintaining the integrity of the gastric mucosa and mediating the protective effects of prostaglandins against gastric mucosal injury. ${ }^{41}$

About one hundred proteins are present in the plasma, they are albumin. Most are made by the liver. They are involved in transport of different substances in the blood including lipids (fatty acids), iron or many drugs. They also participate in blood coagulation, immune defense maintaining blood pressure. ${ }^{15,21}$ Their dosage is used to evaluate the state of hydration, nutritional status, liver, kidney function, or other disease states Inflammation or impaired immune defenses. A reduction in protein is observed in cases of intestinal malabsorption, malnutrition, liver disease, immune deficiency, exocrine pancreatic insufficiency, kidney disease, severe exudative dermatitis, extreme hemorrhage, enteropathies exudative, and infiltrations of the intestine, while an increase in proteins is observed in cases of dehydration, chronic inflammatory process, globulin abnormalities (lymphoma, plasmacytoma), intravascular haemolysis, hyper bilirubinemia and of lipemia. ${ }^{4,24,37}$

\section{Conclusion}

We can conclude from this work that the F.thonningii Blume stem bark hydro-ethanolic extract- contains flavonoids, saponins, quinones, alkaloids, coumarins, catechic tannins, polyphenols, flavonoids, phlebotanins and Antho cyanides. At $500 \mathrm{mg} / \mathrm{kg}$, this extract inhibited pepsin concentration, $\mathrm{XO}$ and MDA; increased, glutathione, catalase activity and SOD. This extract showed a promising pharmacologic and therapeutic activity for the management of ulcers by a gastro protective, anti-ulcer and antioxidant action and not by an antacid action. Administered at $2000 \mathrm{mg} / \mathrm{kg}$, would have a vascular protective effect. This study has also proven the use of Ficus thonnningii in category 1 phyto medicne when use as extemporaneous preparation by tradi practioners, and therefore the possibility of further study for a galenic formulation as an improved traditional product.

\section{Acknowledgments}

None

\section{Conflicts of interest}

The author declares that there are no conflicts of interest.

\section{Funding}

None.

\section{References}

1. Zapata JC, Zepeda GS, Montano LA, et al. The association of helicobacter pylori infection and non-steroidal anti-inflammatory drugs in peptic ulcer disease. Can J Gastroenterol. 2006;20(4):277-280.

2. Ndjitoyap NEC Tzeuton, Njoya C, Tagni O, et al. Tolerance et acceptabilite de l'endoscopie digestive haute: Analyse prospective de 530 examens. Acta Endoscopia. 1998;3(28):226.

3. Li WF, Hao DJ, Fan T, et al. Protective effect of Opiliaceltidifolia leaves against ethanol-induced ulcer in rats. Int J Biol Chem. Sci. $2014 ; 8(6): 2416-2423$.

4. Rachael D, Kennedy H, Erlwanger DM, et al. Phytochemistry, pharmacology and ethnomedicinal uses of ficus thonningii (blume moraceae): A review. Afr $J$ Tradit Complement Altern Med. 2013;10(2):203-212.

5. Usman H, Abdulrahman FI, Usman A. Qualitative phytochemical screening and in vitro antimicrobial effects of methanol stem bark extract of Ficus thonningii (moraceae). Afr J Tradi Comple Alt Med. 2009;6(3):289-295.

6. Lichtenberger LM. The hydrophobic barrier properties of gastrointestinal mucus. Annu Rev Physiol. 1995; 57:565-583.

7. Kato S, Aihara E, Yoshii K, et al. Dual action of prostaglandin $\mathrm{E}_{2}$ on gastric acid secretion through different EP-receptor subtypes in the rat. Am J Physiol Gastrointest Liver Physiol.2005;289(1):G64-G69.

8. Takezono Y, Joh T, Oshima T, et al. Role of prostaglandins in maintaining gastric mucus cell permeability against acid exposure. $J$ Lab Clin Med. 2004;143(1):52-58

9. Kato S, Kawase T, Alderman J, et al. Role of xanthine oxidase in ethanolinduced lipid peroxidation in rats. Gastroenterology, 1990;98(1):203210 .

10. Odebiyi OO, Sofowora EA. Phytochemical screening. Nigeria medical plants II. Lloydia. 1978;41(3):234-246.

11. Sofowora A. Plantes médicinales et médecine traditionnelle d"eAfrique. Paris: Karthala. 1996:378.

12. Brzozowski I, Konturek PC, Brzozowski T, et al. Role of prostaglandin"s, nitric oxide sensory nerves and gastrinin acceleration of ulcer healing by melantonin and its precursor, L-trytophan: J Pineal Res. 2002;32(3):149162.

13. Alcaraz MJ, Hoult JR. Actions of favonoides and the novel antiinflammatory flavones hypolaetin-8-glucoside, on prostaglandine biosynthesis and inactivation. Biochem pharmacol. 1985;34:2477-2482.

14. Bronner C, Landry Y. Kinetics of the inhibitory effect of favonoids on hitamine secretion from mast cells. Agents Actions. 1985;16:147-151.

15. Morikawa T, Li N, Nagatomo A, et al. Triterpene saponins with gastroprotective effects from tea seed ( the seeds of camellia sinensis). $J$ Nat prod. 2006;69(2):185-190.

16. Sun H, Fang WWS, Wang WZ, et al. Structure activity relationships of oleanane and ursane-type triterpenoids. Botanical Studies. 2006;47:339368.

17. Theoduloz C, carrion IB, pertino MW, et al. Potential gastro protective effect of novel cyperenoic acid/quinine derivatives in human cell cultures. Planta Medica. 2012;78(17):1807-1812. 
18. Kishore DV, Pinto J, Mini KV. Anti ulcer activity of methanolic and aqueous extracts of leaves of Sapindus trifoliatus linn. Int J Pharm Sci Rev Res. 2011;6(1):25-27

19. Harju E, Sajanti J. The protective effect of nutrients against stress induce gastric ulcers in the rat. Surg Gynecol Obstet. 1987;165(6):530-534.

20. Tan PV, Nyasse B. Anti-ulcer compound from Voacanga africana with possible histamine $\mathrm{H} 2$ receptor blocking activity. Phytomedicine. 2000;7(6):509-515.

21. OECD Guidelines for the testing of chemicals acute oral toxicity method by acute toxic class. 2001.

22. Mahmood AA, Mariod AA, Al-Bayaty F, et al. Antiulcerogenic activity of Gynura procumbens leaf extract against experimentally induced gastric lesions in rats. J Med Plants Res. 2010;4(8):685-691.

23. Tan PV, Lyonga EL, Nditafon GN, et al. Gastric cytoprotective antiulcerogenic actions of the aqueous bark extract of leaf extract of Eremomastax spesiosa in rats. J Biol Biochem Sci. 1997;7(1):69-77.

24. Mishra HP, Fridovich I. The role of superoxide anion in the autooxidation of epinephrine and a simple assay for superoxide dismutase. The Journal of Biological Chemistry. 1972;247:3170-3175.

25. Ibrahim G, Abdulmumin S, Musa KY, et al. Anticonvulsant activities of Crude Flavonoid Fraction of the Stem bark of Ficus sycomorus (Moraceae). J Pharmacol Toxicol. 2008;3(5):351-356.

26. Ahur VM, Madubunyi I, Adenkola AY, et al. The effect of acetyl acetate extract of Ficus thonningii (Blume) leaves on erythrocyte osmotic fragility and haematological parameters in acetaminophen-treated rats. Com Clin Pathol. 2010;10:1107-1111.

27. Ukwe CV, Ubaka CM, Adibe MO, et al. Antiulcer activity of roots of Zapoteca portoricensis (fam. Fabiaceae). J Basic Clin Pharm. 2010.

28. Benjamin KN, Joseph FM, Mesfin BD, et al. Antiulcerative properties and acute toxicity profile of some African medicinal plant extracts. Journal of Ethnopharmacology. 1994;42(1):13-18.

29. Miller TA, Henagan JM. Indomethacin decreases resistanceof gastric barrier to disruption by alcohol. Dig Dis Sci. 1984;29(2):141-149.

30. Tembe Fokunang EA, Fokunang CN, Ngameni B, et al. Pre-clinical in vitro investigation of the cytotoxic effect of Ficus species on hepatoma G2 cells using two standard toxicity assays. Int J Biol Chem Sci. 2018;12(1):11-23.

31. Nguele RL, Fokunang CN, Etoundi C, et al. Utilisation des especes du genre Aframomum (Aframomum aulacocorpus,. A citratum, A. daniellii) pour le contrôle du poids, le profil lipidique et le statut antioxydant chez les rats Wistar nouris avec une diete atherogene. Int $J$ Biol Chem Sci. 2016;10(6):2575-2586.
32. Eteme FL, Fokunang CN, Tchuenguem F, et al. Epidémiologie moléculaire du Rotavirus du groupe A associé aux gastroentérites chez les enfants de moins de 5 ans dans la ville de Yaoundé (Cameroun). Int J Biol Chem Sci. 2015;9(5):2561-2573.

33. Dongmo MSN, Fokunang CN, Fekam FB, et al. Anticonvulsant activity of extracts from six Cameroonian plants traditionally used to treat epilepsy. Int J Biol Chem Sci. 2014;8(6):2407-2415.

34. Emmanuel E Haule, Mainen J Moshi, Ramadhani SO Nondo, et al. A study of antimicrobial activity, acute toxicity and cytoprotective effect of a polyherbal extract in a rat ethanol- $\mathrm{HCl}$ gastric ulcer model. BMC Res Notes. 2012;5:546.

35. Mainen J Moshi, Ramadhani SO Nondo, Emmanuel E Haule, et al. Antimicrobial activity, acute toxicity and cytoprotective effect of Crassocephalum vitellinum (Benth) S. Moore extract in a rat ethanol- $\mathrm{HCl}$ gastric ulcer model. BMC Res Notes. 2014;7:91.

36. Nahla SaeedAL-Wajeeh, Maryam Hajrezaie, Nawal Al-Henhena, et al. The antiulcer effect of Cibotium barometz leaves in rats with experimentally induced acute gastric ulcer. Drug Des Devel Ther. 2017;11:995-1009.

37. Margaret O Sofidiya, Lilian Agufobi, Abidemi J Akindele, et al. Effect of Flabellaria paniculata Cav. Extracts on gastric ulcer in rats. BMC Complement Altern Med. 2012;12:168.

38. Noraziah Nordin, Suzy Munir Salama, Shahram Golbabapour, et al. Antiulcerogenic effect of methanolic extracts from Enicosanthellum pulchrum (King) Heusden Mehran. PLoS One. 2014;9(11):e111925.

39. Vemo BN, KenfackA, Ngoula F, et al. Effects of ethanol extract of Bersama engleriana leaves on oxidative stress and reproductive parameters in male Guinea pig (Cavia porcellus) exposed to cypermethrin. Int J Biol Chem Sci. 2017;11(5):2243-2253.

40. Yapi AB, Kassi DJ, N'Guessan BY, et al. Etude ethnobotanique des Asteraceae medicinales vendues sur les marches du district autonome d'Abidjan (Cote d'Ivoire). Int J Biol Chem Sci. 2015;9(6):2633-2647.

41. Zakari Abdoul Habou, Mahamadou Chaibou Ibrahim, Hachimou Zabeirou, et al. Efficacité de l'huile de neem (Azadirachta indica) et de Bacillus thuringiensis (Biobit 2X) sur la dynamique de la population de Bemisia tabaci (Gennadius 1889) et Helicoverpa armigera (Hubner, 1808) dans une plantation. Int J Biol Chem Sci. 2016;10(2):497-505. 